\title{
Antecedents Influencing Rugby Migration In South Africa
}

Saré Pienaar, University of Pretoria, South Africa

Karen Koch, University of Pretoria, South Africa

\begin{abstract}
This study set out to determine the most important antecedents influencing the decision of players at the top five South African rugby unions to play overseas. A literature review was conducted in order to establish the theory base for the study. A survey, utilizing a self-administered questionnaire, of players at the top five South African rugby unions was conducted to determine the antecedents influencing the migration decision. The study noted financial reasons as the main antecedent in the decision to migrate. Based on players' opinions, any strategy devised by the rugby unions to address the problem of player migration would have to focus on a number of facets rather than on one single area of concern.
\end{abstract}

Keywords: Sport Labor Migration; Rugby Players; International Labor Migration

\section{INTRODUCTION}

Q

outh Africans will always be passionate about sport and marketers can capitalize on this passion for sport celebrities' (Van Heerden, Kuiper \& Honorata, 2008). Broadcasters pay millions of dollars to rugby unions in order to obtain the rights to televise international and provincial rugby games and research has shown that viewership numbers may be significantly affected if these high profile players do not play (Lunsche, 2007:44-45). Cornelissen \& Solberg (2007:295) already noted that a disadvantage of the loss of players to overseas clubs could result in a decline in the competitiveness of both local teams and the national team. Taking into account the research of Van Heerden et al. (2008), there also are disadvantages in terms of the possible marketing value, which will be lost, should high profile players migrate to overseas clubs. This includes losses for broadcasting companies, losses for unions regarding ticket sales for games as well as marketing value for brand companies paying appearance fees to players for displaying their brand during a match.

It is therefore not surprising that the International Rugby Players Association (IRPA) was concerned about the fact that rugby players are migrating from the southern to the northern hemisphere (Van Reenen, 2009). According to Andy Marinos, South Africa's manager of national teams, the main reason is presumed to be the large amounts of money that rugby players can earn in England and France (Sports24, 2008). The issue of labor migration affects a myriad of sporting disciplines, including American football, athletics, baseball, basketball, cricket, ice hockey, rugby and soccer (or football) (Elliot \& Maguire, 2008:483-484; Maguire \& Pearton, 2000:761). Sport labor migration has been studied quite extensively, with studies into the majority of these areas, although looking at the work produced on this topic over the last two decades; soccer seems to be the sport most comprehensively studied.

Although sport labor migration has been studied extensively in other types of sports, very few studies relating to rugby specifically have been noted. A study on soccer has been carried out in a South African context (Cornelissen \& Solberg, 2007). This study focused on the inward migration of African football players to SA as compared to Europe. Therefore, a need to study the local situation becomes obvious. An awareness of the reasons leading to the decision by top players to compete in overseas leagues may better equip the top rugby unions in SA to manage the problem of losing top players to foreign clubs, this could result in the local unions being more competitive and selling more game tickets. Furthermore, there would be an undeterminable marketing value in the event that these players will stay in South Africa. 
Although one of the main reasons for South African players deciding to play overseas is likely to be the financial benefit, the possibility exists that other reasons may play an important role. The aim of the research was to determine the most important antecedent variables influencing the decision by rugby players from the top five South African rugby unions to migrate to overseas clubs.

To achieve the purpose of the research reported on in this article, a comprehensive literature review was performed in order to establish the theoretical base for the study and to determine the antecedent variables influencing the rugby player's behavior. The literature review is followed by a discussion of the survey performed to determine the importance of the identified variables, a discussion of the results from the survey and concluding with a summary of the research and directions for future research.

\section{LITERATURE REVIEW}

Sayers and Edwards (2004:243-246) observe, "sports are a serious business" and note the importance of sport to a nation's identity, although professional sports stars may be conflicted between advancing their own careers and their feelings of nationalism. 'Ordinary' people are fascinated by sports stars, although professional sports workers are motivated by the same emotional and physical demands as other types of workers.

Sporting talent has become a saleable commodity in the market, and the individuals with the greatest talent are drawn to those clubs most able to reward them for their talent (Cornelissen \& Solberg, 2007:297-299). Sporting talent in less developed nations is often underutilized, with the result that these players migrate to countries, which are comparatively more powerful in the global sports arena. McGovern (2000:401) carried out a study of the migration from Irish football to English league clubs, and its impact on the (resulting) underdevelopment of Irish football. He makes the point that the success of professional football is based solely on its 'employees', being the players. It is argued that the same applies to rugby, as rugby teams also rely on their players for their success.

Collins (2000:71) carried out a review of Australian rugby league players who had gone to play in Britain between 1907 and 1995, to determine the impact of this phenomenon on both countries. He notes that, although globalization in sport had become very topical during the 1990s, global migration in rugby league had been prevailing for more than a century.

Labor migration in rugby has been an issue for many years. The first high-profile migration from SA, in the professional era, occurred when former Springbok captain Francois Pienaar joined Saracens in England in 1997 (Colquhoun, 2002). Since this date, 350 players have left South Africa annually for destinations such as the UK, Ireland, France and Italy (SA Rugby, 2009).

A literature review into the antecedent variables that may potentially impact a professional sport player's decision to migrate to a foreign destination was performed using the ProQuest, EBSCOHost, Emerald and Sabinet databases. In addition, Google Scholar was used to identify any further antecedent variables. A search was also performed on Google to identify possible antecedents that might not have been discussed in academic literature, especially because of the limited academic literature available on South African sports labor migration and sports migration related to rugby players specifically. Based on the available literature, a synthesized list of possible antecedent variables was compiled. Each antecedent is justified with a reason for its inclusion as set out in Table 1. 
Table 1: Antecedent variable with the justification for inclusion

\begin{tabular}{|c|c|}
\hline Antecedent variable & Justification for inclusion \\
\hline $\begin{array}{l}\text { Larger salary or other benefits } \\
\text { payable by the overseas club }\end{array}$ & $\begin{array}{l}\text { Financial benefits were noted as the primary driver in the decision to migrate, both in } \\
\text { previous studies and the printed media (Blitz, 2009; Collins, 2000; Colquhoun, 2002; } \\
\text { Cornelissen \& Solberg, 2007; Elliot \& Maguire, 2008; Magee \& Sugden, 2002; Maguire \& } \\
\text { Pearton, 2000; McGovern, 2000; Ross \& Dunn, 2007; Smith, 2006; Stead \& Maguire, } \\
\text { 2000; The Economist, 2005). }\end{array}$ \\
\hline $\begin{array}{l}\text { Opportunity to receive } \\
\text { sponsorships or endorsements }\end{array}$ & $\begin{array}{l}\text { The opportunity to receive endorsements increases a player's salary and is linked to the } \\
\text { previous antecedent (Harmse and Borchardt, 2009). }\end{array}$ \\
\hline Better long-term tax benefits & $\begin{array}{l}\text { A number of studies found that taxation played a role in the migration decision (Ross \& } \\
\text { Dunn, 2007; Stead \& Maguire, 2000). }\end{array}$ \\
\hline $\begin{array}{l}\text { Quota system in South African } \\
\text { rugby }\end{array}$ & $\begin{array}{l}\text { Both the Management Today Yearbook (2008) and The Economist (2005) have commented } \\
\text { that quotas or affirmative action is partly responsible for South Africans moving overseas. }\end{array}$ \\
\hline $\begin{array}{l}\text { Personal security - the level or } \\
\text { impact of crime in SA }\end{array}$ & $\begin{array}{l}\text { Based on comments in The Economist (2005), it was considered possible that crime played } \\
\text { a role in whether or not to leave SA. }\end{array}$ \\
\hline $\begin{array}{l}\text { Opportunity to play in the } \\
\text { Super } 14 \text { franchise }\end{array}$ & $\begin{array}{l}\text { The opportunity to play in the Super } 14 \text { competition has been noted as a reason for } \\
\text { Australian players not moving overseas (Smith, 2006). }\end{array}$ \\
\hline $\begin{array}{l}\text { Current political situation in } \\
\text { SA }\end{array}$ & $\begin{array}{l}\text { This antecedent is similar to those dealing with the quota system and personal security (or } \\
\text { the impact of crime) (Management Today Yearbook, 2008; The Economist, 2005). }\end{array}$ \\
\hline $\begin{array}{l}\text { Lack of development } \\
\text { opportunities in South African } \\
\text { rugby }\end{array}$ & $\begin{array}{l}\text { Several studies noted that players migrate as a result of a lack of opportunities at home } \\
\text { (Elliot \& Maguire, 2008; Magee \& Sugden, 2002; Sayers \& Edwards, 2004; Stead \& } \\
\text { Maguire, 2000). }\end{array}$ \\
\hline $\begin{array}{l}\text { Security of income }- \text { a } \\
\text { guaranteed basic salary as } \\
\text { opposed to a performance fee }\end{array}$ & $\begin{array}{l}\text { Players' earnings are dramatically reduced if they do not play and therefore do not earn } \\
\text { match fees - this antecedent was included to determine the impact on the players' financial } \\
\text { state of affairs (Stead and Maguire, 2000). }\end{array}$ \\
\hline $\begin{array}{l}\text { Family responsibilities or the } \\
\text { impact on family }\end{array}$ & $\begin{array}{l}\text { The effect on family has been noted as an antecedent in the decision to migrate (Stead \& } \\
\text { Maguire, 2000; The Economist, 2005). Loneliness and homesickness are deemed to be } \\
\text { related to family issues (Sayers \& Edwards, 2004). }\end{array}$ \\
\hline $\begin{array}{l}\text { Opportunity to play for the } \\
\text { Springboks (the South African } \\
\text { national rugby team) }\end{array}$ & $\begin{array}{l}\text { The impact on eligibility for national team selection has been noted as an antecedent in the } \\
\text { decision of whether or not to play overseas (Collins, 2000; Smith, 2006; Smith, 2008). }\end{array}$ \\
\hline $\begin{array}{l}\text { Competitive salary being } \\
\text { offered by the South African } \\
\text { team (in order to retain you) }\end{array}$ & $\begin{array}{l}\text { This antecedent, also related to financial benefits, was included to establish whether it } \\
\text { could play a role in the retention of players, even where financial reasons were the primary } \\
\text { motivation for migrating as the player's financial security would be also improved (Stead } \\
\text { and Maguire, 2000). }\end{array}$ \\
\hline $\begin{array}{l}\text { Opportunity to gain } \\
\text { 'international experience' at } \\
\text { club level or the challenge of } \\
\text { playing in a different league }\end{array}$ & $\begin{array}{l}\text { Several studies found that the opportunity to gain experience at a highly competitive league } \\
\text { was an important antecedent in the decision to migrate (Cornelissen \& Solberg, 2007; Elliot } \\
\text { \& Maguire, 2008; Magee \& Sugden, 2002; Maguire \& Pearton, 2000; McGovern, 2000; } \\
\text { Stead \& Maguire, 2000). }\end{array}$ \\
\hline $\begin{array}{l}\text { Opportunity to coach or be } \\
\text { involved with rugby, but not as } \\
\text { a player }\end{array}$ & $\begin{array}{l}\text { This antecedent was included to determine whether there were other reasons related to } \\
\text { rugby, which may influence the decision to migrate or remain in SA (Sayers \& Edwards, } \\
\text { 2004). }\end{array}$ \\
\hline $\begin{array}{l}\text { Adaptation to the culture of } \\
\text { another country }\end{array}$ & $\begin{array}{l}\text { A number of studies found that the possibility of experiencing other cultures was an } \\
\text { antecedent in the migration decision (Elliot \& Maguire, 2008; Magee \& Sugden, 2002; } \\
\text { Maguire \& Pearton, 2000). Others found that adapting or not to other cultures may } \\
\text { influence the decision to return home (Maguire \& Pearton, 2000). }\end{array}$ \\
\hline Other - please specify & $\begin{array}{l}\text { Respondents were given the opportunity to indicate any other antecedents, which may } \\
\text { influence their decision to play overseas or remain in SA. }\end{array}$ \\
\hline
\end{tabular}

All these antecedents were utilized to compile a questionnaire and conduct a survey, in order to determine the validity and importance of the antecedents in terms of the decision by a rugby player to migrate to an overseas club.

\section{Development of a questionnaire}

The research data were collected using a questionnaire. The questionnaire commenced with a number of simple demographic-type questions before moving on to the questions, which would influence the decision to move overseas or remain in SA (Questions 4 to 6). 
In Question 4, respondents were asked to rate the extent to which a number of antecedents would influence their decision to play for an overseas club or to remain in SA. The question utilized an ordinal Likert scale as only one rating could be selected for each of the antecedents.

Question 5 requested the respondents to rank the top three antecedents influencing the decision to play overseas. This question is classified as a multiple-choice multiple-response question as the three most important antecedents had to be selected from the list provided in Question 4.

In Question 6, respondents had to rank the top three antecedents affecting the decision to remain in SA. This question is classified as a multiple-choice multiple-response question as the three most important antecedents had to be selected from the list provided in Question 4.

In addition, players were requested to indicate whether they were considering moving overseas, partly to establish the extent of the problem. Respondents also had to indicate whether their decision to play overseas would be influenced by the possibility of only South African-based players being eligible for selection to the Springbok national team. A copy of the questionnaire is included as Annexure 1.

Responses were coded into numerical data and analyzed by a research consultant using the Statistical Analysis Software (SAS) package (version 9.1.3).

\section{Population and sample}

A survey, utilizing a self-administered questionnaire, was conducted to determine the most important antecedent variables influencing the decision by rugby players from the top five South African rugby unions to migrate to overseas clubs. The top five rugby unions are the five largest and historically most successful South African rugby unions competing in the Currie Cup and the Super 14 franchise, namely:

- $\quad$ the Blue Bulls, based in Pretoria in Gauteng;

- $\quad$ the Free State Cheetahs, based in Bloemfontein in the Free State;

- $\quad$ the Golden Lions, based in Johannesburg in Gauteng;

- $\quad$ the Natal Sharks, based in Durban in Kwazulu-Natal; and

- Western Province (known as the Stormers in the Super 14 competition), based in Cape Town in the Western Cape.

The questionnaires were couriered or delivered to each of the five rugby unions for distribution to players.

As this was an exploratory study, the sample was not statistically determined. The sample included all those players from the top five South African rugby unions willing to participate in the study. The top five rugby unions were included in the study, as their players are considered more likely to be approached to play overseas. In the past, players from the smaller unions tended to move first to the larger unions before going overseas. As a result, the level of confidence in the results was not determined.

Where any statistical analysis is to be performed, Stutely (cited in Saunders, Lewis \& Thornhill, 2007:211) advises a minimum sample size of 30 . The sampling unit of the study was the individual players (Cooper \& Emory, 1995:200). In order to perform limited statistical analysis, a sample of 50 was targeted, equating to 10 players from each of the five rugby unions involved in the study. Based on information supplied by the five unions, the total population of players in the senior teams is approximately 200 , with an average of 40 players per union.

A total of 90 questionnaires were returned, two of which were deemed to be invalid, as Question 4, which directly addresses the aim of the study, had not been completed. Therefore, a total of 88 valid questionnaires were received. Based on an estimated population of 200, this resulted in a response rate of $44 \%$. This compares favorably with the response rate of $43 \%$ achieved by Stead and Maguire (2000:38) in a similar study. 


\section{Results}

The purpose of the study was descriptive, as it was more concerned with establishing the "who, what, where, when, or how much" of the problem, and less concerned with finding out how one variable influences another or the nature of causal relationships, as is the case in an explanatory study (Cooper \& Emory, 1995:116).

In the first demographic question, respondents had to indicate for which South African rugby union they were currently playing. Based on an average squad of 40 players, the response rate ranged from as low as $20 \%$ for Union E to as high as $67.5 \%$ for Union B, while the response rates for Unions A, C and D were nearer the overall rate of $44 \%$.

The average age of the respondents was 24 years. Of the respondents, $21 \%$ were married, $42 \%$ unmarried but in a committed relationship and 37\% single/divorced/widowed. The expected remaining playing career of the sample as a whole was approximately eight years. The average age at which respondents expected their careers to end was approximately 32 years. This supports the findings in the literature that a professional career in sport tends to be comparatively short (Magee \& Sugden, 2002; Ross \& Dunn, 2007; Sayers \& Edwards, 2004).

The average length of time with the current union was between three and four years, both at an aggregate level and for the individual unions. The only exception was Union E, where the average length of time with the union was less than two years, but it was estimated that this might have been influenced by the small number of respondents from that union.

The experience at a national level has also been evaluated. Only $15 \%$ of the respondents, representing all unions except Union E, indicated that they had previously played for the Springboks.

A review of international experience revealed that seven players, representing all unions except Union D, had played for an overseas club in the past. Five of the players had played in France and two in the UK. This supports the data from SA Rugby (2009) indicating that the majority of players move to either the UK or France when playing overseas. Of the seven players with overseas experience, four had been with the respectable overseas clubs for a year or less, with the remainder having between two and five years' experience with an overseas club. It is impossible to say whether those players with one year or less experience have only just started playing for an overseas club or whether they had returned after only one season. As a result, no significant conclusions could be drawn from this analysis, although it may support the contention that players exploit the fact that the northern and southern hemispheres effectively provide two continuous seasons of play (Elliot \& Maguire, 2008:484; Maguire \& Pearton, 2000:761).

It was not the purpose of this study to generalize the conclusions reached to all rugby players, rather to determine valid antecedent variables influencing the decision of South African rugby players to play overseas. The sample was, therefore, argued to be appropriate in order to support the objectives of this study.

\section{Assessment of intention to play overseas}

In order to establish the extent of the problem of rugby players leaving SA to play overseas, the respondents were asked to indicate whether they were considering leaving their current team to play overseas. When the responses are considered in isolation, the modal response, which accounted for $45 \%$ of the total responses, was that respondents are not currently considering playing overseas. However, given the sensitivity of the question, it could be argued that respondents may have answered 'maybe' instead of 'yes', even if they were at that stage considering playing overseas. When viewed from this perspective, $50 \%$ of respondents did not answer negatively, that is they answered either 'yes' $(22 \%)$ or 'maybe' $(28 \%)$ to the question, with $5 \%$ not responding. It would appear therefore that there is a balance between those considering playing overseas at the time of the survey and those not considering the possibility. The findings are considered to emphasize the severity of the problem. 


\section{Importance of antecedents influencing the decision to play overseas}

Question 4, required of respondents to use a Likert-type scale to rate the extent to which a number of antecedents would influence their decision to play for an overseas club or to stay in SA. Possible responses ranged from 'would definitely make a player move overseas' (a score of 1 ) to 'would definitely make a player stay in SA' (a score of 5).

The responses were analyzed in two ways. Firstly, the percentage of responses falling into each of the categories was compared on an overall basis for each of the antecedents, as set out in Table 2 below, with the modal responses being shaded. Secondly, the average ranking per antecedent was determined per union and for the sample overall, to determine whether each antecedent was more or less likely to influence the decision to play overseas.

Table 2: Breakdown of ranking of antecedents $(n=88$ unless otherwise indicated)

\begin{tabular}{|c|c|c|c|c|c|c|c|}
\hline Antecedent & 1 & 2 & 3 & 4 & 5 & 6 & 7 \\
\hline Larger salary or other benefits payable by the overseas club & $58 \%$ & $41 \%$ & $1 \%$ & - & - & $33 \%$ & \\
\hline Better long-term tax benefits & $34 \%$ & $31 \%$ & $29 \%$ & $3 \%$ & $3 \%$ & $8 \%$ & \\
\hline $\begin{array}{l}\text { Opportunity to gain 'international experience' at club level or } \\
\text { the challenge of playing in a different league }\end{array}$ & $27 \%$ & $44 \%$ & $23 \%$ & $6 \%$ & - & $11 \%$ & \\
\hline Personal security - the level or impact of crime in SA & $19 \%$ & $43 \%$ & $29 \%$ & $3 \%$ & $6 \%$ & $7 \%$ & \\
\hline Opportunity to receive sponsorships or endorsements & $18 \%$ & $38 \%$ & $33 \%$ & $8 \%$ & $3 \%$ & & \\
\hline Quota system in South African rugby & $30 \%$ & $35 \%$ & $25 \%$ & $3 \%$ & $7 \%$ & $9 \%$ & \\
\hline $\begin{array}{l}\text { Security of income - a guaranteed basic salary as opposed to a } \\
\text { performance fee }\end{array}$ & $26 \%$ & $31 \%$ & $30 \%$ & $10 \%$ & $3 \%$ & & \\
\hline Lack of development opportunities in South African rugby & $11 \%$ & $31 \%$ & $52 \%$ & $3 \%$ & $3 \%$ & $7 \%$ & \\
\hline Adaptation to the culture of another country $(n=86)$ & $10 \%$ & $21 \%$ & $45 \%$ & $19 \%$ & $5 \%$ & & \\
\hline $\begin{array}{l}\text { Opportunity to coach or be involved with rugby, but not as a } \\
\text { player }\end{array}$ & $7 \%$ & $18 \%$ & $43 \%$ & $19 \%$ & $13 \%$ & & \\
\hline Current political situation in SA & $9 \%$ & $34 \%$ & $40 \%$ & $11 \%$ & $6 \%$ & & \\
\hline Opportunity to play in the Super 14 franchise & $6 \%$ & $10 \%$ & $23 \%$ & $35 \%$ & $26 \%$ & & $13 \%$ \\
\hline Family responsibilities or the impact on family $(n=87)$ & $14 \%$ & $17 \%$ & $10 \%$ & $49 \%$ & $10 \%$ & & $16 \%$ \\
\hline $\begin{array}{l}\text { Competitive salary being offered by the South African team (in } \\
\text { order to retain you) }\end{array}$ & $9 \%$ & $13 \%$ & $4 \%$ & $36 \%$ & $38 \%$ & & $20 \%$ \\
\hline Opportunity to play for the Springboks $(n=86)$ & $7 \%$ & $3 \%$ & $13 \%$ & $30 \%$ & $47 \%$ & & $27 \%$ \\
\hline Other - related to SA & & & & & & & $7 \%$ \\
\hline
\end{tabular}

Key: $\quad 1=$ Would definitely make you move overseas

2 = Might make you move overseas

$3=$ Would not influence your decision either way

$4=$ Might make you stay in South Africa

$5=$ Would definitely make you stay in South Africa

$6=$ Percentage of times an antecedent was indicated as one of the three most important which would influence the decision to play overseas, excluding no responses $(n=222)$

7 = Percentage of times a antecedent was indicated as one of the three most important which would influence the decision to remain in SA, excluding no responses $(n=163)$

In addition to the antecedents included in the questionnaire, which will be discussed in more detail below, respondents were given the opportunity to indicate any other antecedents, which may influence their decision to play overseas or remain in SA. These will be discussed collectively under 'Other' below.

Larger salary or other benefits payable by the overseas club: The modal response for this antecedent was a ranking of 1 , with $58 \%$ of responses, indicating that the antecedent would definitely make respondents move overseas. In addition, $99 \%$ of respondents ranked the antecedent either as 1 or as 2 and, as a result, the findings indicated that a larger salary is highly likely to influence the decision of players to play overseas. This is confirmed in Maguire and Pearton (2000:761) who remarked, "migration is clearly influenced by the economic rewards available to owners, agents and athletes" and argues that the economic imperative applies most strongly to transitory migration. 
Better long-term tax benefits: Being another financial antecedent, $65 \%$ of respondents ranked this antecedent either as 1 or as 2 , with the modal response being a 1 ranking, with $34 \%$ of responses, indicating that better longterm tax benefits are likely to influence players' decision to migrate. This agrees with the findings by Stead and Maguire (2000:45), who also found that players are motivated to a certain extent by taxation, especially in countries with high tax rates.

Opportunity to receive sponsorships or endorsements: The modal response for this antecedent was a ranking of 2 , with $38 \%$ of responses, while $56 \%$ of respondents ranked the antecedent either as 1 or as 2 , denoting the fact that the opportunity to receive sponsorships would likely influence the decision of players to play overseas. This is arguably linked to the previous antecedent, as it would also result in financial benefits.

Opportunity to gain international experience at club level or the challenge of playing in a different league: Of the sample overall, $71 \%$ of respondents ranked this antecedent either as 1 or as 2, with the modal response being a 2 ranking, with $44 \%$ of responses, suggesting that the opportunity to gain international experience was highly likely to influence the decision of players to move overseas. The results of this study confirmed the findings by Stead and Maguire (2000:45).

Personal security - the level or impact of crime in SA: A total of $62 \%$ of respondents ranked this antecedent either as 1 or as 2 , with the modal response being a 2 ranking, with $43 \%$ of responses. This would suggest that the level or impact of crime in the country is likely to influence the decision of players to move overseas, which bears out statements in the printed media in this regard. It is worth noting that $29 \%$ of respondents indicated that this antecedent would not influence their decision either way.

Quota system in South African rugby: The modal response to the antecedent was a ranking of 2, with 35\% of responses, while $65 \%$ of respondents ranked this antecedent either as 1 or as 2 , leading to the conclusion that the quota system applied in South African rugby is likely to influence the decision of players to migrate. This corresponds with previous literature (Management Today Yearbook, 2008, The Economist, 2005). Even though the current political situation appeared to have a neutral influence on the respondents' decision, it was closely linked to the quota system and was therefore still regarded as a possible antecedent.

Lack of development opportunities in South African rugby: Although the modal response for this antecedent was a 3 ranking, with $52 \%$ of responses, a total of $42 \%$ of respondents ranked this antecedent either as 1 or as 2 . The average ranking of 2.57 would seem to suggest that the antecedent has the potential to influence the decision of players to play overseas, supporting the findings in academic and other literature. To a certain extent, this antecedent could be argued to be related to the quota system in South African rugby, should quotas result in talented players being denied the opportunity to develop or be selected at a higher level of play.

\section{Three most important antecedents affecting the decision to play overseas}

In Question 5, respondents were requested to rank the top three antecedents influencing the decision to play overseas. For each of the antecedents, the number of times a respondent indicated that antecedent as being either the most important, second or third most important antecedent influencing his decision to play overseas was calculated, in order to arrive at the percentage of times a antecedent was selected as being one of the three most important. Antecedents were ranked in descending order based on the percentage calculated for the sample overall. The top five antecedents, based on their overall ranking with their corresponding percentages, are reflected in column 6 in Table 2 above.

The antecedent most mentioned as the most important antecedent, said to influence the decision to play overseas was a larger salary or other benefits payable by the overseas club, this being selected as one of the top three antecedents in $33 \%$ of instances. This supports the findings in the literature that financial reasons are the primary motivator in the decision to migrate. The second most important antecedent identified in this study (11\% of instances) was the opportunity to gain international experience at club level, corroborating the findings of previous studies that the quest for experience was a strong motivator in the decision to play overseas. The third most important antecedent (9\% of instances) was the quota system in South African rugby. The fourth most important 
antecedent ( $8 \%$ of instances) was better long-term tax benefits, which confirms previous findings that taxation plays a role in the decision to migrate. In combined fifth place, were personal security, or the level or impact of crime in SA (7\% of instances), and the lack of development opportunities in South African rugby (7\% of instances). The latter was also noted in the literature as an antecedent in the migration decision. Question 4.

It is also clear that there was a correlation in the results as per Question 5 compared to the results per

Opportunity to play for the Springboks: A total of $77 \%$ of players ranked this antecedent either as 4 or as 5 , with the modal response being a 5 ranking, with $47 \%$ of responses, indicating that the opportunity to play for the Springboks was highly likely to influence the players' decision to remain in SA. This corresponds with findings from previous studies. This antecedent was also considered to relate to the quest for experience noted in the literature. However, $10 \%$ of respondents indicated that this would influence their decision to play overseas, which may again indicate that players frustrated with not being selected for the Springboks may decide to play elsewhere.

Competitive salary being offered by the South African team (in order to retain players): Of the overall sample, $74 \%$ of respondents ranked this antecedent either as 4 or as 5, with the modal response being a ranking of 5, with $38 \%$ of responses, which suggests that a competitive salary being offered to players was highly likely to affect the decision to remain in SA. This was deemed to support the earlier finding that financial reasons were an important consideration in the decision of whether to play overseas or not. As financial reasons have been noted as the most important reason for playing overseas, it would appear that respondents might be persuaded to remain in SA if their union were willing or able to offer them a comparable salary.

Family responsibilities or the impact on family: The modal response to this antecedent was a ranking of 4, with $49 \%$ of responses, while $59 \%$ of respondents ranked the antecedent either as 4 or as 5 , suggesting that players' consideration of family responsibilities and the impact on their family would likely influence the decision to remain in SA. It was noted earlier that $63 \%$ of the respondents were either married or in a committed relationship, and therefore deemed to have a partner to consider in the decision of whether or not to migrate. This was deemed to have been corroborated by these results.

Opportunity to play in the Super 14 franchise: The modal response for this antecedent was a ranking of 4, with $35 \%$ of responses, and $61 \%$ of respondents ranked this antecedent either as 4 or as 5 . This would indicate that the opportunity to play in the Super 14 competition is likely to influence the decision of players to remain in SA, supporting previous literature (Smith, 2006).

Other $(\mathbf{n}=\mathbf{2 6}$ ): The other antecedents noted by respondents were observed to influence the migration decision both positively and negatively. The responses were categorized as follows:

- $\quad$ A few of the respondents noted the fact that they were nearing the end of their career, and indicated that this would influence the decision to play overseas, supporting the findings in literature that players tend to want to maximize their earnings towards the end of their career (Magee \& Sugden, 2002; Ross \& Dunn, 2007; Sayers \& Edwards, 2004).

- Twelve of the respondents noted antecedents related to SA as a reason to keep playing in SA, including the weather, culture and language, the quality of life and their love for the country, which validates comments in the printed media regarding the reasons for Australian players choosing to remain in Australia rather than move overseas (Hughes, 2006; Smith, 2006).

\section{Three most important antecedents affecting the decision to remain in SA}

Question 6 required respondents to rank the top three antecedents affecting the decision to remain in SA. For each of the antecedents, the number of times a respondent noted that antecedent as either the most important, second or third most important antecedent influencing his decision to remain in SA was calculated, to determine the percentage of times a antecedent was selected as being one of the three most important. Antecedents were again ranked in descending order based on the percentage calculated for the sample overall. The top five antecedents (based on their overall ranking) with their corresponding percentages are reflected in column 7 Table 2 above. 
Based on the information in Table 2, the most important antecedent influencing the decision to remain in SA was the opportunity to play for the Springboks, that being selected as one of the top three antecedents in $27 \%$ of instances. This arguably links to the quest for experience noted in previous studies. The second most important antecedent identified in this study (20\% of instances) was a competitive salary being offered by the unions in order to retain players, which may be considered to be similar to the most important antecedent in the previous question. In other words, although money is the most important antecedent in the decision to migrate, the decision may be reversed if the South African union offers a comparable salary. The third most important antecedent (16\% of instances) was players' responsibility towards their families and the impact a decision to move overseas would have on their families, confirming previous research.

A clear correlation in the results as per Question 6 compared to the results per Question 4 can be noted. The single antecedent, which could influence a rugby player to stay, appeared to be selected for the national team, the Springboks. However, when respondents were asked whether they would stay in SA if only players playing in SA were eligible for selection as Springboks (Question 8), only 32\% of the respondents indicated that this fact would make them stay in SA.

\section{Correlation between a number of demographic factors and the decision to play overseas}

The correlation between the respondents' age, expected remaining playing career and marital status and the intention to play overseas was determined individually for each of the demographic characteristics, in order to evaluate whether any of these factors would specifically influence the decision to play overseas.

In order to test whether any relationship existed between the different variables mentioned above, a chisquare test was performed, with a $p$-value being determined. The $p$-value was then compared to the level of significance (or alpha) (Cooper \& Emory, 1995:441). In this case, where the $p$-value was less than 0.05, the relationship between the variables was deemed to be significant (at the $95 \%$ level of confidence).

In order to determine the correlation between marital status and the intention to play overseas, a chi-square test was performed on the responses to Question 10 (marital status) and Question 12 (intention to play overseas). The results are set out in Table 3 below.

Table 3: Correlation between marital status and the intention to play overseas $(n=83)$

\begin{tabular}{|l|c|c|c|c|}
\hline \multicolumn{1}{|c|}{ Marital status } & $\begin{array}{c}\text { Yes } \\
\text { (frequency and } \\
\text { column percentage) }\end{array}$ & $\begin{array}{c}\text { No } \\
\text { (frequency and } \\
\text { column percentage) }\end{array}$ & $\begin{array}{c}\text { Maybe } \\
\text { (frequency and } \\
\text { column percentage) }\end{array}$ & $\begin{array}{c}\text { Total (frequency } \\
\text { and column } \\
\text { percentage }\end{array}$ \\
\hline Single-/-divorced-/-widowed & $7(22.58 \%)$ & $16(51.61 \%)$ & $8(25.81 \%)$ & $31(100 \%)$ \\
\hline $\begin{array}{l}\text { Unmarried, but in a } \\
\text { committed relationship }\end{array}$ & $3(8.57 \%)$ & $19(54.29 \%)$ & $13(37.14 \%)$ & $35(100 \%)$ \\
\hline Married & $8(47.06 \%)$ & $5(29.41 \%)$ & $4(23.53 \%)$ & $17(100 \%)$ \\
\hline Total & $18(21.69 \%)$ & $40(48.19 \%)$ & $25(30.12 \%)$ & $83(100 \%)$ \\
\hline
\end{tabular}

The $p$-value of 0.0337 indicates that there is a relationship between marital status and the intention to play overseas at the $95 \%$ level of confidence.

Based on the results of the test, as set out in Table 3 above, those respondents who had indicated that they were married were more likely to migrate than those who were single or unmarried, but in a committed relationship. These results contradict the earlier findings, which indicated that players' consideration of family responsibilities and the impact on their family would likely influence the decision to remain in South Africa. This may warrant further investigation.

It should, however, be remembered that a correlation between two factors does not necessarily indicate a causal relationship (Leedy \& Ormrod, 2005:267). The correlation could, hypothetically, be ascribed to the fact that married players are generally older, with age being the cause of the correlation, rather than marital status. 
In order to determine the correlation between both age and expected remaining playing career and the intention to play overseas, and owing to the fact that the sample was relatively small and not normally distributed, a Kruskal-Wallis one-way analysis of variance test was performed on the responses to Question 9 (age), Question 11 (expected remaining playing career) and Question 12 (intention to play overseas). The results are set out in Table 4 below.

Table 4: Correlation between age and expected remaining playing career and the intention to play overseas $(n=82)$

\begin{tabular}{|l|c|c|c|}
\hline \multicolumn{1}{|c|}{ Independent variable } & No & Maybe \\
\hline Age (years) & $25.28^{\mathrm{a}}$ & $23.56^{\mathrm{b}}$ & $24.68^{\mathrm{ab}}$ \\
\hline Mean value & 2.97 & 3.31 & 2.38 \\
\hline Standard deviation & 18 & 39 & 25 \\
\hline $\mathrm{n}$ & \multicolumn{3}{|}{} \\
\hline Expected remaining career (years) & $7.74^{\mathrm{ab}}$ & $8.79^{\mathrm{a}}$ & $7.00^{\mathrm{b}}$ \\
\hline Mean value & 2.75 & 2.89 & 2.38 \\
\hline Standard deviation & 19 & 38 & 25 \\
\hline $\mathrm{n}$ & & & \\
\hline
\end{tabular}

The $p$-value for the relationship between age and the intention to play overseas was 0.0361 , indicating a relationship between the two variables at the $95 \%$ level of confidence.

Upon further analysis of the information presented in Table 4 above, the relationship was found to be significantly different at the $10 \%$ level of significance for those responding 'yes' and 'no', indicating that players who intended playing overseas were significantly older than those not considering migrating.

The $p$-value for the relationship between expected remaining playing career and the intention to play overseas was 0.0295 , indicating a relationship between the two variables at the $95 \%$ level of confidence.

Upon further consideration of the information contained in Table 4 above, the relationship was noted to be significantly different at the $5 \%$ level of significance for those responding 'no' and 'maybe', indicating that players who might have been considering playing overseas had a significantly shorter expectation of their remaining playing career than those who were not considering a move overseas.

The results of the analysis of the correlation between age, expected remaining playing career and intention to play overseas supports the findings in the literature, that is, that players tend to consider migration as a means of maximizing their earnings towards the end of their career (Magee \& Sugden, 2002; Ross \& Dunn, 2007; Sayers \& Edwards, 2004).

The three most important antecedents noted by respondents in the decision to migrate were a larger salary or other benefits payable by the overseas club, the opportunity to gain international experience at club level or the challenge of playing in a different league, and the quota system in South African rugby. The three most important antecedents identified by respondents in the decision to remain in SA were the opportunity to play for the Springboks, a competitive salary being offered by the South African team (in order to retain players), and family responsibilities or the impact on family.

Based on the responses to the open-ended question, it is recommended that unions apply a multifaceted approach in order to retain players, focusing on increased financial benefits and improving the relationship between the unions and the players.

\section{CONCLUSION}

The main aim of the research on which this article is based, was to determine the most important antecedent variables leading to the overseas migration of rugby players from the top five South African rugby unions.

Possible antecedents were identified by means of a literature review. The influence of these antecedents was included in the questionnaire to determine their importance on the decision to play overseas or remain in South Africa. The responses to the antecedents included in the questionnaire were judgmentally grouped into three 
categories based on the average ranking according to the Likert results. Antecedents with an average ranking of less than 2.8 were considered likely to influence the decision to play overseas, antecedents with an average ranking of more than 3.2 were considered likely to influence the decision to remain in South Africa, while those with an average ranking of between 2.8 and 3.2 were considered unlikely to influence the decision either way. The results of this analysis are set out in Table 5 below.

Table 5: Categorization of antecedents according to the impact on the decision to play overseas or remain in South Africa

\begin{tabular}{|c|c|c|}
\hline $\begin{array}{c}\text { Antecedents likely to influence the } \\
\text { decision to play overseas }\end{array}$ & $\begin{array}{l}\text { Antecedents likely to influence the } \\
\text { decision to remain in South Africa }\end{array}$ & $\begin{array}{c}\text { Antecedents unlikely to influence the } \\
\text { decision either way }\end{array}$ \\
\hline $\begin{array}{l}\text { - } \begin{array}{l}\text { Larger salary or other benefits } \\
\text { payable by the overseas club }\end{array} \\
\text { Opportunity to gain 'international } \\
\text { experience' at club level or the } \\
\text { challenge of playing in a different } \\
\text { league } \\
\text { - } \quad \text { Better long-term tax benefits } \\
\text { Quota system in South African } \\
\text { rugby } \\
\text { - } \quad \text { Personal security - the level or } \\
\text { impact of crime in South Africa } \\
\text { Security of income - a guaranteed } \\
\text { basic salary as opposed to a } \\
\text { performance fee } \\
\text { Opportunity to receive sponsorships } \\
\text { or endorsements } \\
\text { Lack of development opportunities } \\
\text { in South African rugby } \\
\text { Current political situation in South } \\
\text { Africa }\end{array}$ & $\begin{array}{l}\text { - } \begin{array}{l}\text { Family responsibilities or the impact } \\
\text { on family }\end{array} \\
\text { Opportunity to play in the Super } 14 \\
\text { franchise } \\
\text { - Competitive salary being offered by } \\
\text { the South African team (in order to } \\
\text { retain players) } \\
\text { Opportunity to play for the } \\
\text { Springboks }\end{array}$ & $\begin{array}{l}\text { Adaptation to the culture of another } \\
\text { country } \\
\text { Opportunity to coach or be involved } \\
\text { with rugby, but not as a player }\end{array}$ \\
\hline
\end{tabular}

From the above analysis, the antecedent most likely to influence players' decision to move overseas is the financial benefits associated with playing for an overseas club, while the antecedent most likely to influence the respondents' decision to remain in South Africa, is the opportunity to play for the Springbok national team.

Based on the results of the chi-square test to determine the relationship between marital status and the intention to play overseas, those respondents who had indicated that they were married were more likely to migrate than those who were single or unmarried but in a committed relationship. This contradicts the findings that family responsibilities are more likely to cause players to remain in South Africa and may warrant further investigation.

The results of this study, as well as previous research, noted financial reasons as the main antecedent in the decision to migrate. On a practical level, given the concern regarding migration in rugby at international level, it is argued that awareness of the antecedents leading to the decision by top players to play for overseas leagues may better equip the top five rugby unions in South Africa to manage the problem of losing top players to foreign clubs, which could lead to the local unions being more competitive.

It is recommended that unions apply a multifaceted approach when considering a retention strategy, focusing on increased financial benefits, game time and other opportunities, as well as improving the relationship between the unions and the players.

The research was limited to rugby and owing to the delineation in the focus of the study, the results may not be readily generalizable to other unions, countries or sporting disciplines, although, the findings were aligned to those of previous research conducted in the field of sport labor migration. Some of the antecedents' numbers could have been interpreted as an antecedent to make the decision either to migrate overseas or to stay in SA. However, this risk is neutralized by questions asking for the top three antecedents, which could influence the decision to move overseas, and for the top three antecedents, which could influence the decision to stay in SA. Future research could be extended to all the unions in the country or include other major sporting disciplines like cricket or soccer. 
It is hoped that this research project will contribute to a greater understanding of the problem of overseas migration of South African rugby players as well as a broader understanding of the concept of sport labor migration in general.

\section{AUTHOR INFORMATION}

Saré Pienaar, senior lecturer in the Department of Taxation at the University of Pretoria, South Africa. Currently involved in various research projects in tax, focusing on human behavior regarding taxation as well as the applicability of tax policy in terms of the internet transactions. E-mail: sare.pienaar@up.ac.za (Corresponding author)

Karen Koch, M Com student in the Department of Taxation at the University of Pretoria, South Africa.

\section{REFERENCES}

1. Blitz, R. (2009). Tax plan aims to level soccer's playing field. Financial Times, 24 March:6. Retrieved from: http://0proquest.umi.com.innopac.up.ac.za/pqdweb?did=1666325951\&sid=6\&Fmt=3\&clientId=15443\&RQT =309 $\&$ VName $=$ PQD.

2. Collins, T. (2000). From Bondi to Batley: Australian players in British Rugby League 1907-1995. Sporting Traditions, 16(2):71-86. Retrieved from: http://www.la84foundation.org/SportsLibrary/SportingTraditions/2000/st1602/ST1602i.pdf.

3. Colquhoun, A. (2002). Will the last Springbok to leave the Republic please turn off the light. Inside Rugby, (2):52-54. Retrieved from: http://0web.ebscohost.com.innopac.up.ac.za/ehost/detail?vid=5\&hid=112\&sid=3bbf781b-d8a3-47de-9d71d0ea45554376\%40sessionmgr113\&bdata=JnNpdGU9ZWhvc3QtbGl2ZSZzY29wZT1zaXRl\#db=s3h\&AN $=9015034$.

4. $\quad$ Cooper, D.R. \& Emory, C.W. (1995). Business research methods. $5^{\text {th }}$ ed. Boston, Massachusetts: Irwin/McGraw-Hill.

5. Cornelissen, S. \& Solberg, E. (2007). Sport mobility and circuits of power: the dynamics of football migration in Africa and the 2010 World Cup. Politikon: South African Journal of Political Studies, 34(3):295-314. Retrieved from: http://0-

web.ebscohost.com.innopac.up.ac.za/ehost/detail?vid=8\&hid=105\&sid=5b00d856-d2af-40b8-98cedc7bac53442c\%40sessionmgr112\&bdata=JnNpdGU9ZWhvc3QtbGl2ZSZzY29wZT1zaXRl\#db=s3h\&AN $=9015034$.

6. Elliot, R. \& Maguire, J. (2008). Thinking outside of the box: exploring a conceptual synthesis for research in the area of athletic labor migration. Sociology of Sport Journal, 25(4):482-497. Retrieved from: http://0web.ebscohost.com.innopac.up.ac.za/ehost/pdf?vid=1\&hid=117\&sid=102fc269-e893-4246-ae20cc32c8e92af0\%40sessionmgr109.

7. Harmse, J.J. \& Borchardt, D.J.( 2009). Bok-miljoenêrs - groot geld om spelers in SA te hou. Rapport, 25 January: 1.

8. Hughes, M. (2006). Henry adds key chapter to Arsenal's moving story. The Times, 20 May:112. Retrieved from: http://0-web.ebscohost.com.innopac.up.ac.za/ehost/detail?vid=1\&hid=112\&sid=9cf54c16-b8354851-906d-a47c59376f07\%40sessionmgr108\&bdata=JnNpdGU9ZWhvc3QtbGl2ZSZz Y29wZT1zaXRl\#db=nfh\&AN=7EH1080693709.

9. Leedy, P.D. \& Ormrod, J.E. 2005. Practical research: planning and design. 8th ed. Upper Saddle River, New Jersey: Pearson Education.

10. Lunsche, S. (2007). Who holds the power? Journal of Marketing, Feb/Mar:44-45. Retrieved from: http://0search.sabinet.co.za.innopac.up.ac.za/WebZ/Authorize?sessionid=0\&bad=ejour/ejour badsearch.html\&por tal=ejournal\&style=ejour\&next=images/ejour/images/ejour/mfsa1/mfsa1_feb_2007_a26.pdf\&clientid=284 $\underline{0}$.

11. Magee, J. \& Sugden, J. (2002). "The world at their feet": professional football and international labor migration. Journal of Sport and Social Issues, 26(4):421-437. Retrieved from: Sage Publications: http://jss.sagepub.com/cgi/reprint/26/4/421. 
12. Maguire, J. \& Pearton, R. (2000). The impact of elite labour migration on the identification, selection and development of European soccer players. Journal of Sports Sciences, 18(9):759-769. Retrieved from: http://0-web.ebscohost.com.innopac.up.ac.za/ehost/pdf?vid=1\&hid=107\&sid=bf532331-bb79-45e5-9cc28616ff1446c5\%40sessionmgr104.

13. Mail \& Guardian online. (2007). Union tackles ban on overseas Boks. Retrieved from: http://www.mg.co.za/article/2007-08-05-union-tackles-ban-on-overseas-boks.

14. Marinos, A. (2008). Plans to stop Bok exodus. Retrieved from: http://www.sport24.co.za/Rugby/Plans-tostop-Bok-exodus-20080904.

15. Management Today Yearbook. (2008). Capitalising on the Rugby World Cup success. Management Today Yearbook, 23(10):22. Retrieved from: http://0search.sabinet.co.za.innopac.up.ac.za/WebZ/Authorize?sessionid=0\&bad=ejour/ejour badsearch.html\&por

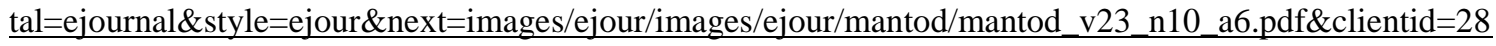
$\underline{40}$.

16. $\quad \overline{M c G o v e r n, ~ P . ~(2000) . ~ T h e ~ I r i s h ~ b r a w n ~ d r a i n: ~ E n g l i s h ~ L e a g u e ~ c l u b s ~ a n d ~ I r i s h ~ f o o t b a l l e r s, ~ 1946-1995 . ~}$ British Journal of Sociology, 51(3):401-418. Retrieved from: Wiley Interscience: http://0www3.interscience.wiley.com.innopac.up.ac.za/cgi-bin/fulltext/119033327/PDFSTART.

17. Ross, J.M \& Dunn, R.R. (2007). The income tax responsiveness of the rich: evidence from free agent Major League Baseball all-stars. Contemporary Economic Policy, 25(4):639-648. Retrieved from: http://0web.ebscohost.com.innopac.up.ac.za/ehost/pdf?vid=1\&hid=116\&sid=89e4c553-cb49-42d5-b90df7743eff02ec\%40sessionmgr108.

18. SA Rugby. ( $\quad$ michelee@ sarugby.co.za) (2009). Information on overseas players. [E-mail to:] Koch, K. (karen.koch@eskom.co.za).

19. Saunders, M., Lewis, P. \& Thornhill, A. (2007). Research methods for business students. $4^{\text {th }}$ ed. Harlow, Essex: Pearson Education.

20. Sayers, J. \& Edwards, M. (2004). The brawn-drain? Issues for the professional sports worker. In: Spoonley, P., Dupuis, A. \& De Bruin, A. (eds.). Work and working in twenty-first century New Zealand, 243-248. Palmerston North, New Zealand: Dunmore Press. Retrieved from: http://muir.massey.ac.nz/bitstream/10179/548/3/bdifse.pdf.

21. Smith, W. (2006). Reds retain Blake, their ace in the pack. The Australian, 26 May:41. Retrieved from: http://0-web.ebscohost.com.innopac.up.ac.za/ehost/detail?vid=1\&hid=114\&sid=2121bff5-69ca-4010-8d4d0a79b0b7ace3\%40sessionmgr108\&bdata=JnNpdGU9ZWhvc3QtbGl2ZSZzY29wZT1zaXRl\#db=nfh\&AN $=200605261041372911$.

22. Smith, W. (2008). Sharpe, Hoiles stay loyal to Wallabies. The Australian, 4 March:18. Retrieved from: http://0-web.ebscohost.com.innopac.up.ac.za/ehost/detail?vid=1\&hid=103\&sid=74a7ac97-90e0-43ab-b11f3863d80e05b0\%40sessionmgr103\&bdata=JnNpdGU9ZWhvc3QtbG12ZSZzY29 wZT1zaXRl\#db=nfh\&AN=200803041018535210.

23. Stead, D. \& Maguire, J. (2000). "Rite de passage" or passage to riches?: the motivation and objectives of Nordic/Scandinavian players in English League soccer. Journal of Sport and Social Issues, 24(1):36-60. Retrieved from: http://jss.sagepub.com/cgi/reprint/24/1/36.pdf.

24. The Economist. (2005). Home, sweet home - for some. The Economist, 376(8439):37-38. Retrieved from: http://0-web.ebscohost.com.innopac.up.ac.za/ehost/detail?vid=1\&hid=105\&sid=59be01f5-9904-4a57$\underline{8 \mathrm{e} 11-}$ 7ebe7e6fffa4\%40sessionmgr107\&bdata=JnNpdGU9ZWhvc3QtbG12ZSZzY29wZT1zaXR1\#db=aph\&AN= 17921368 .

25. Van Heerden, N., Kuiper, A \& Honorata, M (2008). Investigating sport celebrity endorsement and sport event sponsorship as promotional cues. South African Journal for Research in Sport, Physical Education and Recreation, 30(2) 147-165. Retrieved from: http://t063.camel.ntcpe.edu.tw/ezcatfiles/t063/download/attdown/0/\%D7\%5B\%B4\%DC\%20celebrity\%20e ndorsement.pdf.

26. Van Reenen, R. (ross@ @ mba-uk.co.za) (2009). Tesis. [E-mail to:] Koch, K. (karen.koch@eskom.co.za) 16 June 2009. 
ANNEXURE A

For office use only

Number

\section{QUESTIONNAIRE}

Please tick the box on the right to indicate your consent to take part in this study

Please indicate your choice, either by circling or marking with an $\mathrm{X}$, the number next to the appropriate response (unless otherwise indicated)

1. Which South African rugby union are you currently playing for?

\begin{tabular}{|l|l|}
\hline Blue Bulls & 1 \\
\hline Free State Cheetahs & 2 \\
\hline Golden Lions & 3 \\
\hline Natal Sharks & 4 \\
\hline Western Province & 5 \\
\hline
\end{tabular}

\begin{tabular}{|l|l|}
\hline $\mathrm{V} 1$ & \\
\hline
\end{tabular}

2. How long (in years) have you been playing for the team indicated above?

\begin{tabular}{|l|l|}
\hline V2 & \\
\hline
\end{tabular}

3.a) Are you currently also contracted to an overseas club or have you played for an overseas club in the past?

\begin{tabular}{|l|l|}
\hline Yes & 1 \\
\hline No & 2 \\
\hline
\end{tabular}

\begin{tabular}{|l|l|}
\hline V3 & \\
\hline
\end{tabular}

3.b) If you answered yes to the previous question, please indicate the last country you played in and state the name of the club

\begin{tabular}{|c|c|}
\hline Club in the UK - please specify $\ldots \ldots \ldots \ldots \ldots \ldots \ldots$ & 1 \\
\hline Club in France - please specify $\ldots \ldots \ldots \ldots \ldots \ldots \ldots$ & 2 \\
\hline Club in Australia - please specify .................. & 3 \\
\hline Club in New Zealand - please specify .............. & 4 \\
\hline Other - please specify $\ldots \ldots \ldots \ldots \ldots \ldots \ldots \ldots \ldots \ldots \ldots \ldots \ldots \ldots \ldots \ldots \ldots$ & 5 \\
\hline
\end{tabular}

3.c) How long did you or have you been playing for the club indicated in the previous question? (answer in years or months, if less than a year)

4. If given the opportunity to play overseas on a long-term or extended basis, please rate the

\begin{tabular}{|l|l|}
\hline V5 & \\
\hline
\end{tabular}
extent to which the following factors would influence your decision to move to an overseas club or remain in South Africa. Please mark the appropriate option with an X.

Please consider all the factors even if you are not currently contemplating moving overseas 


\begin{tabular}{|c|c|c|c|c|c|c|}
\hline & Factor & $\mathbf{1}$ & 2 & 3 & 4 & 5 \\
\hline 1. & Larger salary or other benefits payable by the overseas club & & & & & \\
\hline 2. & Opportunity to receive sponsorships or endorsements & & & & & \\
\hline 3. & Better long-term tax benefits & & & & & \\
\hline 4. & Quota system in South African rugby & & & & & \\
\hline 5. & $\begin{array}{l}\text { Personal security - the level of crime in South Africa or } \\
\text { impact thereof }\end{array}$ & & & & & \\
\hline 6. & Opportunity to play in the Super 14 franchise & & & & & \\
\hline 7. & Current political situation in South Africa & & & & & \\
\hline 8. & Lack of development opportunities in South African rugby & & & & & \\
\hline 9. & $\begin{array}{l}\text { Security of income - a guaranteed basic salary as opposed } \\
\text { to a performance fee }\end{array}$ & & & & & \\
\hline 10. & Family responsibilities / impact on family & & & & & \\
\hline 11. & Opportunity to play for the Springboks & & & & & \\
\hline 12. & $\begin{array}{l}\text { Competitive salary being offered by the South African team } \\
\text { (in order to retain you) }\end{array}$ & & & & & \\
\hline 13. & $\begin{array}{l}\text { Opportunity to gain 'international experience' at club level / } \\
\text { challenge of playing in a different league }\end{array}$ & & & & & \\
\hline 14. & $\begin{array}{l}\text { Opportunity to coach or be involved with rugby, but not as } \\
\text { a player }\end{array}$ & & & & & \\
\hline 15. & Adaptation (or not) to the culture of another country & & & & & \\
\hline 16. & Other - please specify $\ldots \ldots \ldots \ldots \ldots \ldots \ldots \ldots \ldots$ & & & & & \\
\hline 17. & Other - please specify $\ldots \ldots \ldots \ldots \ldots \ldots \ldots \ldots \ldots$ & & & & & \\
\hline
\end{tabular}

\begin{tabular}{|l|l|}
\hline V6 & \\
\hline V7 & \\
\hline V8 & \\
\hline V9 & \\
\hline V10 & \\
\hline V11 & \\
\hline V12 & \\
\hline V13 & \\
\hline V14 & \\
\hline V15 & \\
\hline V16 & \\
\hline V17 & \\
\hline V18 & \\
\hline V19 & \\
\hline V20 & \\
\hline V21 & \\
\hline V22 & \\
\hline
\end{tabular}

Key: $\quad \mathbf{1}=$ Would definitely make you move overseas

$\mathbf{2}=$ Might make you move overseas

$\mathbf{3}=$ Would not influence your decision either way

$4=$ Might make you stay in South Africa

$\mathbf{5}=$ Would definitely make you stay in South Africa

5. Of the factors ranked 1 or 2 in Question 4, please indicate the three most important factors which could influence your decision to move overseas. Start with the most important factor, then the second most important and lastly, the third most important factor - please write down the factor or the number associated with it in Question 4

1)

2)

3)

\begin{tabular}{|l|l|}
\hline V23 & \\
\hline V24 & \\
\hline V25 & \\
\hline
\end{tabular}

6. Of the factors ranked 4 or 5 in Question 4, please indicate the three most important factors which could influence your decision to stay in South Africa. Start with the most important factor, then the second most important and lastly, the third most important factor - please write down the factor or the number associated with it in Question 4

1)

2)

3)

7. Have you ever played for the Springboks (senior national team)?

\begin{tabular}{|l|l|}
\hline Yes & 1 \\
\hline No & 2 \\
\hline
\end{tabular}

\begin{tabular}{|l|l|}
\hline V26 & \\
\hline V27 & \\
\hline V28 & \\
\hline
\end{tabular}

\begin{tabular}{|l|l|}
\hline V29 & \\
\hline
\end{tabular}


8. If only players playing in South Africa were eligible for selection as Springboks, would this make you stay in South Africa?

\begin{tabular}{|l|l|}
\hline Yes & 1 \\
\hline No & 2 \\
\hline Maybe & 3 \\
\hline No opinion & 4 \\
\hline
\end{tabular}

\begin{tabular}{|l|l|}
\hline V30 & \\
\hline
\end{tabular}

9. How old are you? (in years)

\begin{tabular}{|l|l|}
\hline V31 & \\
\hline
\end{tabular}

10. Please select one option which best describes your marital status

\begin{tabular}{|l|l|}
\hline Single / divorced / widowed & 1 \\
\hline Unmarried, but in a committed relationship & 2 \\
\hline Married & 3 \\
\hline
\end{tabular}

\begin{tabular}{|l|l|}
\hline V32 & \\
\hline
\end{tabular}

11. How many more years do you expect to play rugby professionally?

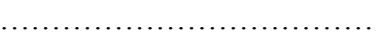

\begin{tabular}{|l|l|}
\hline V33 & \\
\hline
\end{tabular}

12. Are you considering leaving the South African team you are currently playing for in order to move overseas?

\begin{tabular}{|l|l|}
\hline Yes & 1 \\
\hline No & 2 \\
\hline Maybe & 3 \\
\hline
\end{tabular}

\begin{tabular}{|l|l|}
\hline V34 & \\
\hline
\end{tabular}

13. Are you assisted by any of the following in planning and/or managing your financial affairs? Please mark the appropriate option with an $\mathrm{X}$

\begin{tabular}{|l|l|l|}
\hline & Yes & No \\
\hline Financial advisor & & \\
\hline Tax advisor & & \\
\hline Accountant & & \\
\hline Lawyer & & \\
\hline Agent & & \\
\hline Other - please specify $\ldots \ldots \ldots \ldots \ldots \ldots \ldots$ & & \\
\hline
\end{tabular}

\begin{tabular}{|l|l|}
\hline V35 & \\
\hline V36 & \\
\hline V37 & \\
\hline V38 & \\
\hline V39 & \\
\hline V40 & \\
\hline
\end{tabular}

14. Please indicate one thing which your rugby union could do to keep you playing in South Africa

Thank you very much for your participation in the study and the time taken to complete the questionnaire. 